\title{
Coagulant potentials of Moringa oleifera seeds in water purification
}

\author{
R. V. Thorat, D. A. Malvekar and *A. U. Sutar
}

ISSN 0971 - 6920 (Print)

\author{
S. G. M. College, \\ KARAD, SATARA-415 124 (M.S.) INDIA \\ *Corresponding Author \\ E-mail-ausutar@gmail.com
}

Received : 25.08.2020; Revised : 15.09.2020; Accepted : 22.10.2020

\begin{abstract}
The main objective of this study is to confirm the potentials of Moringa oleifera seeds over alum for water purification. Various doses of Moringa seed powder 4, 8, $12 \mathrm{~g} / \mathrm{l}$ were taken and checked for treatment of river and sewage water. After treatment of seed powder with water samples were analyzed for physico-chemical parameters like $\mathrm{pH}$, Absorbance, TDS, TSS, Hardness, Chlorides, Conductivity, Turbidity, MPN and DO. Almost all parameters showed reduction with increasing dosage of Moringa seed powder. Similar doses of alum were checked with river water sample and were analyzed for above mentioned parameters. The results obtained showed that seed powder (natural coagulant) is more effective than conventional chemical coagulant., alum. The seed of Moringa oleifera is cheap, eco-friendly and non-toxic, can be effectively used as a coagulant for river and sewage water purification.

Figures : 03

References : 10

Tables : 03

KEY WORDS : Coagulant potentials, Moringa oleifera, Purification
\end{abstract}

\section{Introduction}

Potable water is one of the basic needs of all living organisms including humans. About $71 \%$ of the Earth's surface is water-covered. Out of this, only $2 \mathrm{ppm}$ $(0.0002 \%)$ of water is found in rivers across the world. Waste water is also generated from the river water which contains bodily wastes (faeces and urine), washing water, laundry wastes, etc. It is mainly termed as sewage water. Pollution of river water can lead to various water borne diseases like diarrhea, amoebiasis, typhoid, etc. Safe drinking water is essential to the health and welfare of a community and so water should be purified before consumption 4 .

Various water treatment methods are used at small scale level like coagulation-flocculation, sedimentation, filtration and disinfection, often by chlorine, before distribution of treated water to consumers ${ }^{9}$. Nowadays aqua-technology containing $\mathrm{RO}$ water purifiers is widely used for water purification. But this technique is quite expensive for the common consumers.

The study is primarily focusing on Moringa oleifera seeds as a natural polyelectrolyte which can be used as a coagulant to clarify turbid river and sewage waters. M. oleifera is among the 14 species of trees that belong to the family Moringaceae ${ }^{5}$. The conventional method of using high levels of chemical coagulant alum (aluminium sulphate) is a risk factor for Alzheimer's disease ${ }^{3}$. The use of $M$. oleifera seeds has an advantage over the chemical treatment methods as it is herbal and less expensive.
This work was carried out to study the coagulant potentials of $M$. oleifera powder extracted from mature and dried Moringa oleifera seeds against the alum available from the market.

\section{Materials and Methodology Coagulants used}

Dry Moringa oleifera (drumstick) seeds used in this study were collected from local fields of Karad town, Maharashtra. The shells covering the seeds were removed and fine powder was prepared using mortar and pestle. This dried powder was kept in hot air oven at $40^{\circ} \mathrm{C}$ for one hour and was directly used as a natural coagulant. The aluminium sulphate (alum) crystal powder used in this study was obtained from local grocery store in Karad, Maharashtra.

\section{Sample Collection}

Ten liters of river water samples were collected from Krishna River, Karad and five liters of sewage water samples were collected from Krishna Canal, Karad. The water samples were collected in containers which were cleaned priorly by detergent to avoid impurities.

The untreated river and sewage water samples were immediately used for the study and before treatment various parameters were analyzed. These physicochemical parameters include $\mathrm{pH}$, Absorbance, Total Dissolved Solids (TDS), Hardness (total and permanent), Total Suspended Solids (TSS), Chlorides, Conductivity, Turbidity, Most Probable Number (MPN) and Dissolved Oxygen (DO). Before treatment characteristics of the 


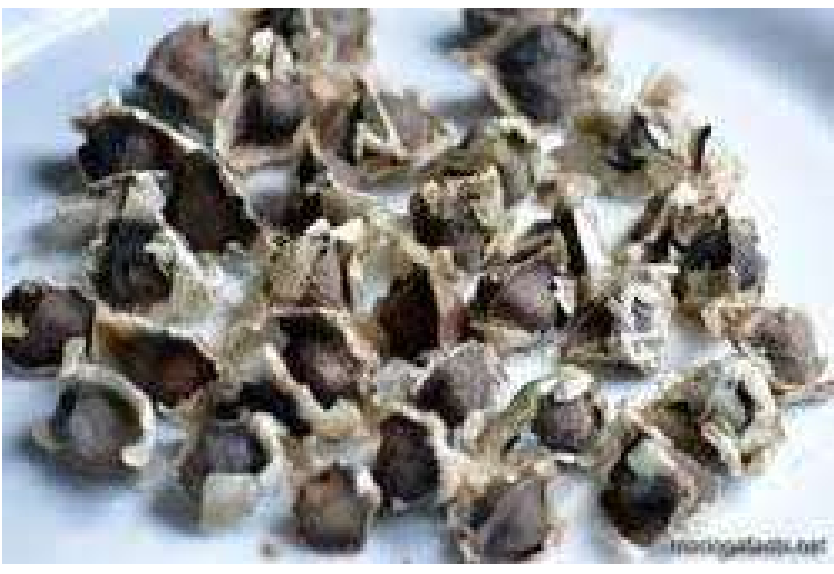

Fig.1: Moringa oleifera seeds

untreated river and sewage samples (Table-1).

Treatment of river and sewage water with Moringa oleifera seed powder

Three different concentrations of doses of M. oleifera seed powder i.e. 4,8 and $12 \mathrm{~g} / \mathrm{l}$ each of river and sewage water were selected for treatment. The $M$. oleifera seed powder was mixed in both river and sewage water and allowed to settle for 1-1.5 hours. After sedimentation, the treated water was filtered using

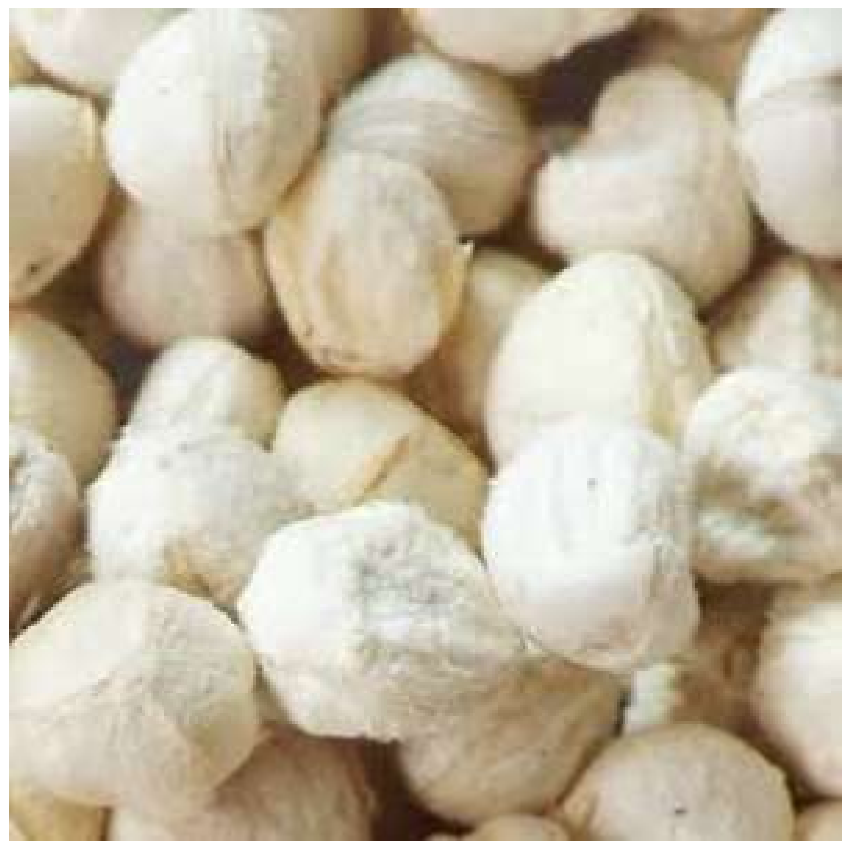

Fig.2 : Moringa oleifera shelled seeds.

Whatman filter paper (42 pore size). The water quality parameters were studied for understanding physicochemical characteristics as given in standard APHA methods ${ }^{2}$.

TABLE-1 : Characeristics of river and sewage water samples before treatment.

\begin{tabular}{|c|c|c|c|}
\hline S. No. & Parameter & $\begin{array}{c}\text { River water sample } \\
\text { value }\end{array}$ & $\begin{array}{c}\text { Sewage water sample } \\
\text { value }\end{array}$ \\
\hline 1. & $\mathrm{pH}$ & 8 & 10.5 \\
\hline 2. & Absorbance (at $450 \mathrm{~nm})$ & 0.13 & 0.21 \\
\hline 3. & Total Dissolved Solids[TDS] (mg/l) & 0.4 & 0.3 \\
\hline 4. & $\begin{array}{l}\text { Hardness }(\mathrm{mg} / \mathrm{l}) \\
\text { Total Permanent }\end{array}$ & $\begin{array}{c}140.6 \\
132\end{array}$ & $\begin{array}{c}601.2 \\
412\end{array}$ \\
\hline 5. & Total Suspended Solids [TSS] (mg/l) & 1400 & 1540 \\
\hline 6. & Chlorides(mg/l) & 212.7 & 177.25 \\
\hline 7. & Conductivity(S/m) & 2500 & 1910 \\
\hline 8. & Turbidity (NTU) & 168 & 105 \\
\hline 9. & Most Probable Number(MPN) & 129.56 & 84.61 \\
\hline 10. & Dissolved Oxygen [DO] (mg/l) & 3.42 & 4.42 \\
\hline
\end{tabular}


Treatment of river water with Alum (aluminium sulphate)

Similarly, three different concentrations of doses of alum crystal powder i.e. $4,8,12 \mathrm{~g} / \mathrm{l}$, each of river water were selected for treatment. The alum powder was mixed in river water and allowed to settle for 1 hour. After sedimentation, the treated water was filtered using Muslin cloth and water quality parameters were checked.

A $1000 \mathrm{ml}$ of distilled water with no $M$. oleifera powder or alum was kept as a control.

\section{Laboratory Analysis}

pH and Absorbance measurement

The $\mathrm{pH}$ of the water samples was found out using $\mathrm{pH}$ paper indicator (Litmus paper). The change in color indicated the $\mathrm{pH}$ of the water samples. Absorbance was measured using a digital colorimeter at $450 \mathrm{~nm}$ as the water samples contained coloured impurities ${ }^{2}$.

\section{TDS, Hardness and TSS}

These parameters were analyzed using the procedure as described by the standard APHA methods

TABLE-2 : Treatment of river and sewage water samples by $M$. oleifera seed powder at different concentrations

\begin{tabular}{|c|c|c|c|c|c|c|c|c|}
\hline \multirow[t]{3}{*}{$\begin{array}{l}\text { S. } \\
\text { No. }\end{array}$} & \multirow[t]{3}{*}{ Parameter } & \multirow[t]{3}{*}{$\begin{array}{c}\text { D/w } \\
\text { (Control) }\end{array}$} & \multicolumn{6}{|c|}{$\begin{array}{l}\text { Treatment with } M \text {. oleifera seed powder } \\
\text { (in grams) }\end{array}$} \\
\hline & & & \multicolumn{3}{|c|}{$\begin{array}{l}\text { River water } \\
\text { samples }\end{array}$} & \multicolumn{3}{|c|}{$\begin{array}{l}\text { Sewage water } \\
\text { samples }\end{array}$} \\
\hline & & & $4 \mathrm{~g} / \mathrm{l}$ & $8 g / 1$ & $12 \mathrm{~g} / \mathrm{l}$ & $4 g / l$ & $8 g / l$ & $12 \mathrm{~g} / \mathrm{l}$ \\
\hline 1 & $\mathrm{pH}$ & 7 & 6 & 5.5 & 6.8 & 9.5 & 9 & 7.5 \\
\hline 2 & Absorbance(at $450 \mathrm{~nm})$ & 0.11 & 0.13 & 0.12 & 0.11 & 0.2 & 0.14 & 0.11 \\
\hline 3 & $\begin{array}{l}\text { Total Dissolved Solids } \\
\text { [TDS] }(\mathrm{mg} / \mathrm{l})\end{array}$ & 0.1 & 0.6 & 0.3 & 0.15 & 0.3 & 0.2 & 0.1 \\
\hline 4 & $\begin{array}{l}\text { Hardness }(\mathrm{mg} / \mathrm{l}) \\
\text { Total } \\
\text { Permanent }\end{array}$ & $\begin{array}{l}24.6 \\
15.2\end{array}$ & $\begin{array}{l}86.6 \\
61.2\end{array}$ & $\begin{array}{l}63.2 \\
49.2\end{array}$ & $\begin{array}{l}52 \\
44\end{array}$ & $\begin{array}{l}244.6 \\
183.2\end{array}$ & $\begin{array}{l}106.6 \\
64.6\end{array}$ & $\begin{array}{c}61.2 \\
42\end{array}$ \\
\hline 5 & $\begin{array}{l}\text { Total Suspended Solids } \\
\text { [TSS] }(\mathrm{mg} / \mathrm{l})\end{array}$ & 550 & 880 & 350 & 150 & 1420 & 1285 & 500 \\
\hline 6 & Chlorides(mg/l) & 106.35 & 184.34 & 155.98 & 127.62 & 141.8 & 141.8 & 113.4 \\
\hline 7 & Conductivity(S/m) & 300 & 2500 & 1600 & 800 & 1500 & 560 & 270 \\
\hline 8 & Turbidity (NTU) & 1.00 & 85 & 26 & 4 & 90 & 20 & 3 \\
\hline 9 & $\begin{array}{l}\text { Most Probable Number } \\
\text { (MPN) }\end{array}$ & 50.25 & 110.25 & 76.33 & 25.64 & 112.30 & 80.45 & 67.96 \\
\hline 10 & $\begin{array}{l}\text { Dissolved Oxygen } \\
\text { [DO] }(\mathrm{mg} / \mathrm{l})\end{array}$ & 2 & 3.20 & 3.10 & 2.80 & 4.42 & 3.38 & 1.12 \\
\hline
\end{tabular}


of examination of water purity.

\section{Chloride Test}

Chloride content in the untreated and treated samples was estimated by using Mohr's method of titration ${ }^{2}$.

\section{Conductivity and Turbidity measurement-}

Conductivity of water samples were determined using digital conductivity meter. The reading was recorded from the LCD display after stabilization. While turbidity measurements were carried out using INSIF digital turbidity meter. The turbidity of the water samples was displayed on the LCD panel in Nephelometric Turbidity Units (NTU).After each reading, both the instruments were calibrated with distilled water prior to using the next sample.

Most Probable Number (MPN) and Dissolved Oxygen (DO)-

Total coli form count of before and after treatment water samples was carried out using Mac Conkey's broth. Double and single strength tubes containing Mac Conkey's broth with Durham's tubes were used. After incubation for $24 \mathrm{~h}$ at $37^{\circ} \mathrm{C}$, the coli form count was analyzed.

Dissolved Oxygen was estimated by Winkler method following the standard guidelines recommended by APHA standards.

\section{Results and Discussion}

The treatment with Moringa oleifera shows better results than alum for the water treatment.

In order to determine the adequate condition for the activity of the coagulants, the concentrations were taken as $4 \mathrm{~g}, 8 \mathrm{~g}$ and $12 \mathrm{~g}$ and the results obtained are presented (Tables 2 and 3 ). The comparative study of some important physico- chemical characters of river water with Moringa seed and alum powders at various concentrations. Optimum results were obtained for water

TABLE-3 : Treatment of river and sewage water samples by Alum powder at different concentrations

\begin{tabular}{|c|c|c|c|c|c|}
\hline $\begin{array}{l}\text { S. } \\
\text { No. }\end{array}$ & Parameter & $\begin{array}{l}\text { Distilled water } \\
\text { (Control) }\end{array}$ & \multicolumn{3}{|c|}{$\begin{array}{l}\text { Treatment with Alum powder } \\
\text { (in grams) }\end{array}$} \\
\hline & & & \multicolumn{3}{|c|}{ River water samples } \\
\hline & & & $4 g / 1$ & $8 g / l$ & $12 \mathrm{~g} / \mathrm{l}$ \\
\hline 1 & $\mathrm{pH}$ & 7 & 6 & 4 & 6.5 \\
\hline 2 & Absorbance(at $450 \mathrm{~nm})$ & 0.11 & 0.14 & 0.12 & 0.11 \\
\hline 3 & Total Dissolved Solids[TDS] (mg/l) & 0.1 & 0.3 & 0.2 & 0.2 \\
\hline 4 & $\begin{array}{l}\text { Hardness }(\mathrm{mg} / \mathrm{l}) \\
\text { Total } \\
\text { Permanent }\end{array}$ & $\begin{array}{l}24.6 \\
15.2\end{array}$ & $\begin{array}{l}128.6 \\
115.2\end{array}$ & $\begin{array}{c}108 \\
101.2\end{array}$ & $\begin{array}{c}92 \\
73.2\end{array}$ \\
\hline 5 & Total Suspended Solids[TSS] (mg/l) & 550 & 1330 & 1285 & 990 \\
\hline 6 & Chlorides(mg/l) & 106.35 & 248.15 & 212.7 & 170.16 \\
\hline 7 & Conductivity(S/m) & 300 & 2000 & 1700 & 1000 \\
\hline 8 & Turbidity (NTU) & 1.00 & 150 & 95 & 6 \\
\hline 9 & Most Probable Number(MPN) & 50.25 & 290.10 & 150.15 & 113.50 \\
\hline 10 & Dissolved Oxygen [DO] (mg/l) & 2 & 4.4 & 4.2 & 3.6 \\
\hline
\end{tabular}




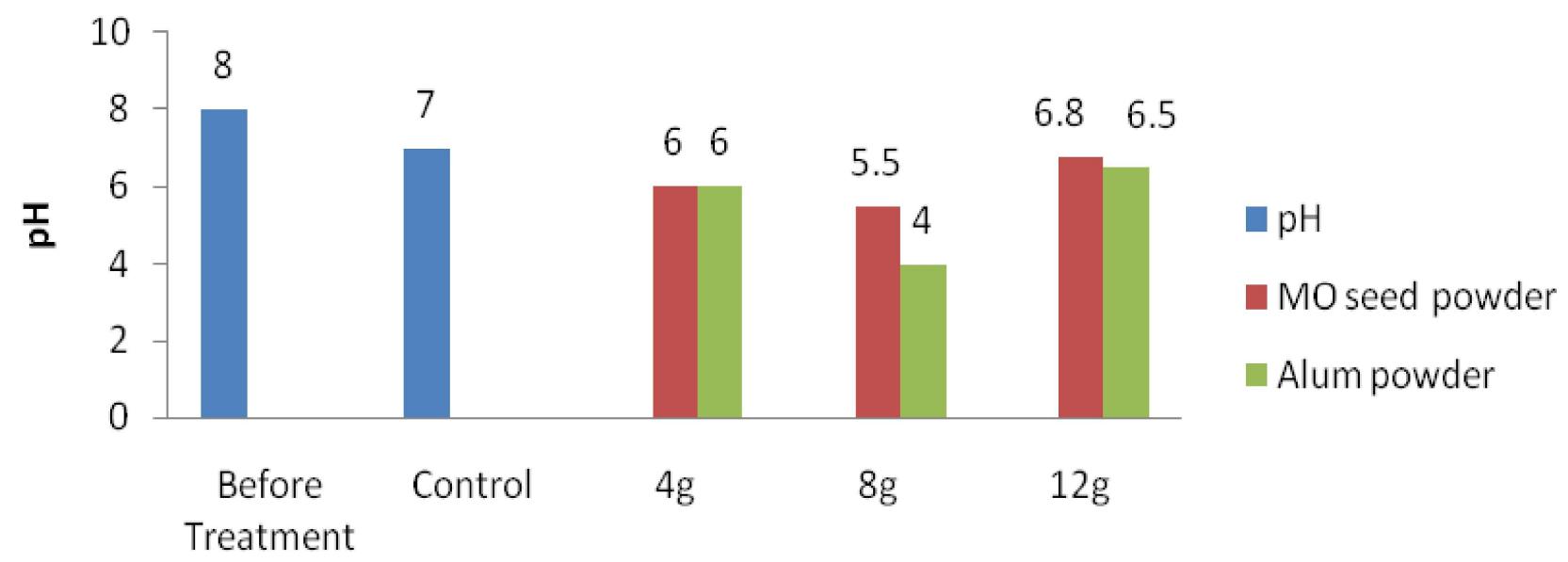

Fig. 3 a) Effect of $M$. oleifera seed and alum powders on $\mathrm{pH}$ content of river water

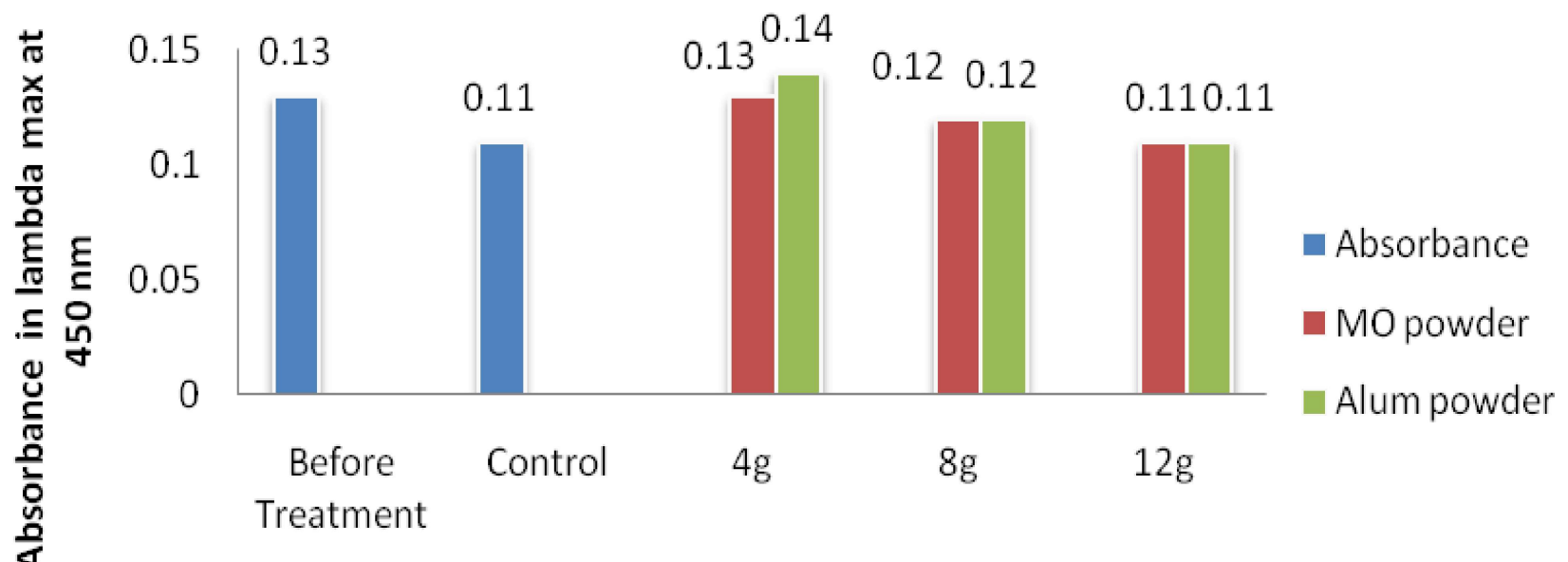

Fig. 3 b) Effect of $M$. oleifera seed and alum powders on absorbance content of river water

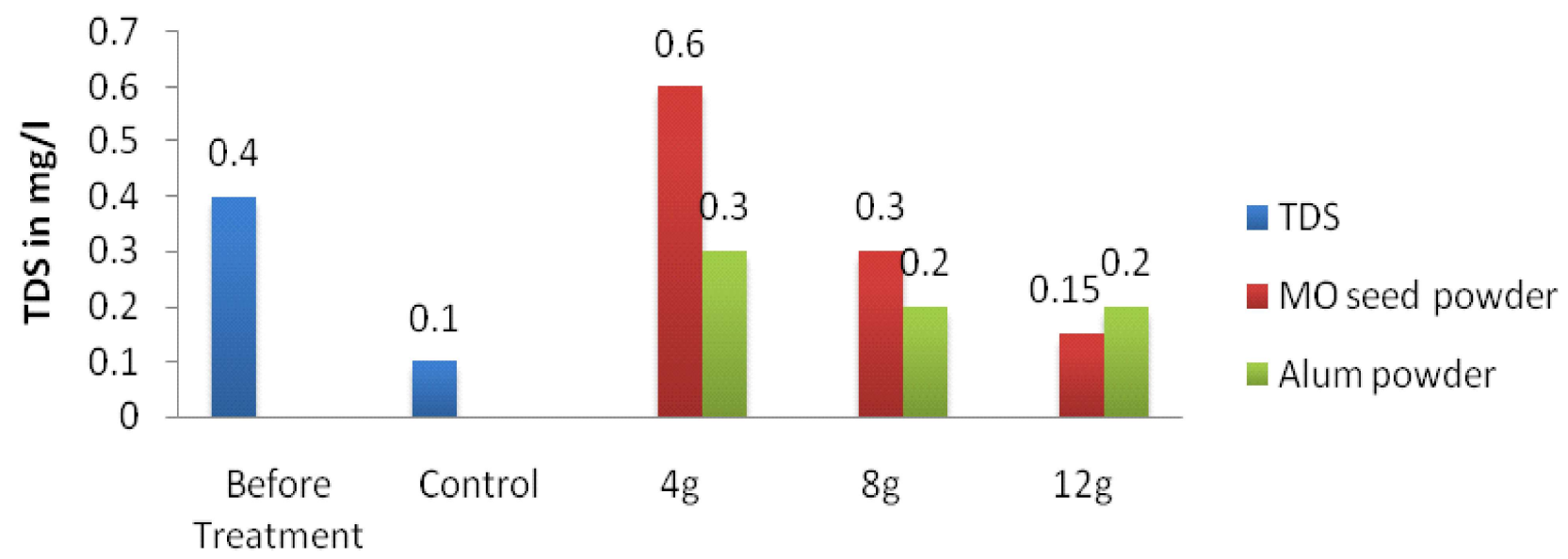

Fig. 3 c) Effect of $M$. oleifera seed and alum powders on TDS content of river water 

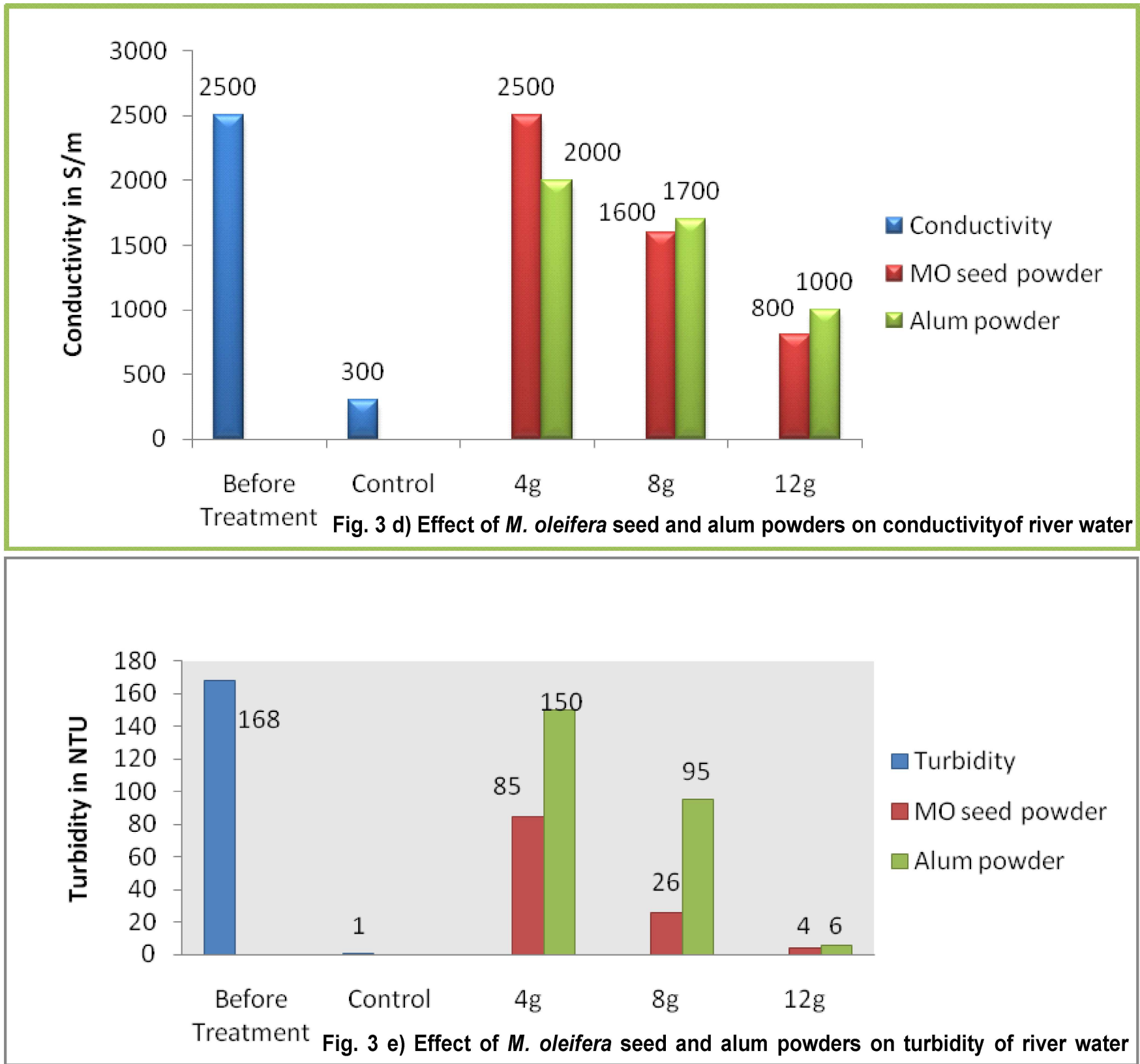

Fig. 3 : Comparative study of some physico-chemical characters of river water before and after treatment with $M$. oleifera $\mathrm{O}$ seed powder and Alum powder at Different concentration.

samples with both $M$. oleifera seed and alum powders at $12 \mathrm{~g}$ concentration.

The $\mathrm{pH}$ of sewage sample before and after treatment shows decrease in value with increasing dosage of $M$. oleifera seed powder. In comparative study, river water treated with $M$. oleifera seeds shows better results than alum powder. This could be explained by the fact that the solutions were becoming acidic due to sulphuric acids produced by alum in river water. This reduced its $\mathrm{pH}^{6}$ (Fig.- 3a). Absorbance of sewage sample as seen in Table-2, reduces by increasing the concentration of Moringa seed powder. It has a relationship with colour. Initial brownish green colour of sewage water lessened after treatment with natural coagulant with $12 \mathrm{~g}$ concentration. Both $M$. oleifera and alum coagulants show similar absorbance as presented (Fig 3b). The initial TDS content of sewage water was $0.3 \mathrm{mg} / \mathrm{l}$. But after treatment with Moringa seed powder with $12 \mathrm{~g}$ dosage, it was found to be $0.1 \mathrm{mg} / \mathrm{l}$ which is equal to control $(\mathrm{d} / \mathrm{w})$. Moringa oleifera is known to be a natural cationic polyelectrolyte containing up to six amino acids of mainly glutamic acid, methionine and arginine ${ }^{8}$. After treatment, initially the TDS count increased with addition of $M$. oleifera seed powder than alum powder at $4 \mathrm{~g}$ dosage. But later on it decreased with increasing concentration (Fig. 3c).

Initially the total and permanent hardness of both sewage and river water was more. But after the treatment with high doses of the respective coagulants, it decreased. 
M. oleifera seed powder removes hardness in water through adsorption and inter-particle bridging mechanism ${ }^{8}$. The initial TSS count of sewage water was $1540 \mathrm{mg} / \mathrm{l}$. But it decreased upto $500 \mathrm{mg} / \mathrm{l}$ at $12 \mathrm{~g}$ of dosage of $M$. oleifera seed powder. Also the initial TSS count of river water was $1400 \mathrm{mg} / \mathrm{l}$ and it decreased upto $150 \mathrm{mg} / \mathrm{l}$ at $12 \mathrm{~g}$ dosage when treated with $M$. oleifera seed powder. While in case of alum treatment, TSS count decreased upto $990 \mathrm{mg} / \mathrm{l}$ at $12 \mathrm{~g}$ dosage. The chloride content of sewage water initially was $177.25 \mathrm{mg} / \mathrm{l}$ which after $M$. oleifera seed powder treatment at higher concentration decreased to $113.4 \mathrm{mg} / \mathrm{l}$. Chlorides in river water before treatment were $212.7 \mathrm{mg} / \mathrm{l}$ which decreased to $127.62 \mathrm{~m}$ $\mathrm{g} / \mathrm{l}$ at $12 \mathrm{~g}$ of $M$. oleifera seed powder concentration. While it decreased to $170.16 \mathrm{mg} / \mathrm{l}$ at $12 \mathrm{~g}$ of alum powder concentration. It is because cations from Moringa seed attract the negatively charged chloride ions present in water and neutralize it ${ }^{7}$.

Conductivity is directly linked to the concentration of ions in the water and determines purity of water ${ }^{1}$. In this study, the initial conductivity of sewage and river water was $1910 \mathrm{~S} / \mathrm{m}$ and $2500 \mathrm{~S} / \mathrm{m}$ respectively. After treatment of sewage water with $M$. oleifera seed powder, it decreased to $270 \mathrm{mg} / \mathrm{l}$ at $12 \mathrm{~g}$ dosage. Also after treatment of river water with $M$. oleifera seed and alum powders, at high concentration $(12 \mathrm{~g})$, the conductivity decreased upto $800 \mathrm{~S} / \mathrm{m}$ and $1000 \mathrm{~S} / \mathrm{m}$. M. oleifera seed powder showed better results than alum powder (Fig. 3d). The degree of turbidity depends upon the concentration or dispersion of the suspended matter and the light absorption properties of the suspension ${ }^{1}$. Tables 1 and 2 show that turbidity of untreated sewage water decreased tremendously after treatment with high dosage of $M$. oleifera seed powder, (Fig. 3e) shows better results of $M$. oleifera seed powder than alum powder at various concentrations.

The MPN count of coli forms according to Mc Cardy's chart of sewage and river water initially were 84.61 and 129.56 respectively. After treatment of sewage water with $M$. oleifera seed powder at $4 \mathrm{~g}$ dosage, the MPN count was 112.30 which decreased to 67.96 at $12 \mathrm{~g}$ dosage. The results showed decreasing MPN count in treated river water samples with increasing concentrations of natural and chemical coagulants respectively. The study shows that the dissolved oxygen of treated sewage water decreased at higher concentrations $12 \mathrm{~g}$ than DO at other concentrations. The DO content of pre-treated river water was 3.42. Tables 2 and 3 show the DO contents of river water with $M$. oleifera seed and alum powders at various concentrations.

\section{Conclusion}

The results obtained show that $M$. oleifera seed powder has coagulant potentials and is better than the chemical coagulant, alum. Also, it shows good results at high dosage while checking various parameters like $\mathrm{pH}$, Absorbance, TDS, Hardness, TSS, Chlorides, Conductivity, Turbidity, MPN and DO. Therefore, it is concluded that the seeds of Moringa oleifera which is easily available, eco-friendly and non-toxic can be used in water purification treatments.

\section{References}

1. Aminu MD, Garba ZY. Abba. Biosorption Potentials of Moringa oleifera seed in Textile Effluent Treatment. 5, ISSN 2229-5518.

2. APHA, AWWA, WEF. Standard methods of examination of water and wastewater, $20^{\text {th }}$ edition, IWA Publishing Washington DC, American public health association, 2005.

3. Crapper DR, Krishnan SS, Dalton AJ. Brain aluminium distribution in Alzheimer's disease and experimental neurofibrillary degeneration. Sci. 1973; 180(4085): 511-513.

4. Eman N Ali, Suleyman A Muyibi, Hamzah M Salleh, Mohd Ramlah M Salleh, Md Zahangir Alam. Moringa oleifera seeds as natural coagulant for water treatment.IWTC. 2009; 13 : Hurghada, Egypt.

5. Folkard GK, Sutherland J, Shaw R. Water clarification using Moringa oleifera seed coagulant, Intermediate Technology Publications, London (United Kingdom). 1999; 109-112.

6. Francis Kweku Amagloh, Amos Benang. Effectiveness of Moringa oleifera seed as coagulant for water purification. 2009; 4 (1) : 119-123.

7. Mangale SM, Chonde SG, Jadhav AS, Raut PD. Study of Moringa oleifera (Drumstick) seed as natural absorbent and antimicrobial agent for ground water treatment, Research Journal of Recent Sciences. 2012 ; (3): 31-40.

8. Muyibi SA, Evison LM. Moringa oleifera seeds for softening hard water; Water Resources. 1995a; 29(4): 10991105.

9. Ndabigengengesere A, Narasiah KS. "Quality of water treated by coagulation using Moringa oleifera seeds." 1998; 32 (2) : 701.

10. Patil SB, Patil BV. Evaluation of water quality parameters of valvan dam water for drinking purpose. Flora and fauna. 2020; 26 (1) : 96-98. 